\title{
Olfactory discrimination in rats with hippocampal lesions
}

No impairment was seen in the acquisition of an olfactory discrimination following large bilateral hippocampal lesions in rats.

The hippocampus responds to olfactory bulb stimulation in cats (Berry et al, 1962), rabbits, and rats (Cragg, 1960), and the anatomical base for such hippocampal activity has been well outlined (Pribram \& Kruger, 1954; Blackstad, 1958; Cragg, 1961). Although lesions in prepyriform cortex, periamygdaloid cortex, and the olfactory tubercle, all of which receive fibers from the olfactory bulb, produce degenerating fibers in the hippocampus and fascia dentata (Blackstad, 1958; Cragg, 1961), behavioral studies have not demonstrated any significant effect of hippocampal lesions on olfactory discrimination (Swann, 1934, 1935; Allen, 1940, 1941; Brown \& Ghiselli, 1938). Only Brown and Ghiselli, however, have studied olfactory discrimination acquisition in hippocampally-lesioned rats, and these workers (as well as Swann) used creosote, which stimulates the trigeminal nerve as well as olfactory receptors (Allen, 1937) as one of the discriminanda. The present study reports the effect of hippocampal lesions on olfactory discrimination acquisition in rats using odors which are not known trigeminal stimulants.

Method

Ss were male Sprague-Dawley rats, previously used in a spontaneous alternation study, about 170 days old at the beginning of this experiment. Surgery was done when Ss were 70-95 days old. Lesions were produced by aspiration in one stage under Nembutal (50 mg/kg) anesthesia as described previously (Kimble, 1963). Eleven Ss received bilateral lesions of the hippocampus and overlying cortical tissue, $10 \mathrm{Ss} \mathrm{re-}$ ceived lesions of just the overlying neocortical Hissue, and $11 \mathrm{Ss}$ were unoperated. When the experiment was over, Ss were sacrificed, the brains removed, frozen, sectioned at $14 \mathrm{m \mu}$ and stained with thionin. An examination of the lesioned brains revealed that all of the hippocampal Ss had sustained large dorsal hippocampal lesions that severed the hippocampus bilaterally. The fimbria was also typically destroyed, but the ventral $1 / 3$ of the hippocampal formation was intact. Damage was also seen in the corpus callosum and lateral nucleus of the thalamus. The neocortically lesioned Ss also sustained damage to the corpus callosum. ${ }^{2}$ Representative frontal sections of a hippocampal $\mathrm{S}$ are shown in Fig. 1.

The apparatus was a plywood $Y$-maze, painted gray, with a hardware cloth floor and top. The stem was 16 in. long, each arm 13-1/2 in. long, the width was 5 in. throughout. A $6 \times 2$ in. partition 6 in. from the end of each arm hid the water bottle spout. Two metal tea caddies, each containing cotton soaked in one of the extracts to be discriminated (anise and peppermint) were suspended in the arm entrance. A small vial containing another extract-soaked cotton wad was placed beneath the water spout.

Ss were placed on a $24 \mathrm{~h}$ water deprivation schedule five days prior to their introduction to the maze. On Day $1, \mathrm{~S}$ was given $10 \mathrm{~min}$ adaptation in the maze; training began on Day 2. Ss received 10 trials/day; mean intertrial interval was $15 \mathrm{~min}$. The positive cue was varied from arm to arm according to a Gellerman sequence. About half of each group was trained to anise odor, the other half to peppermint. Between trials the maze was sprayed with a room deodorant and the air flushed out. One day after reaching a 9/10 correct criterion Ss were given 10 "blank" trials with thoroughly washed tea caddies to insure that the discrimination had been formed on the basls of the cues explicitly provided by $\mathrm{E}$. Results

There was no deficit in the hippocampally-lesioned Ss and no significant differences among groups on the acquisition of the olfactory discrimination. The unoperated Ss took an average (mean) of 81 trials to reach criterion, as compared with 83 trials for the hippocampals and 97 for the neocortically-damaged Ss (see Table 1). All Ss performed near chance level (50\%) on the 10 "blank" trials. There was a slight and statistically unreliable $(p<.10)$ tendency for the hippocampal Ss trained to approach anise to reach criterion sconer than the hippocampal Ss trained to approach peppermint.

\section{Discussion}

Our results support those of Brown \& Ghiselll (1938) that an intact hippocampus is not necessary for the

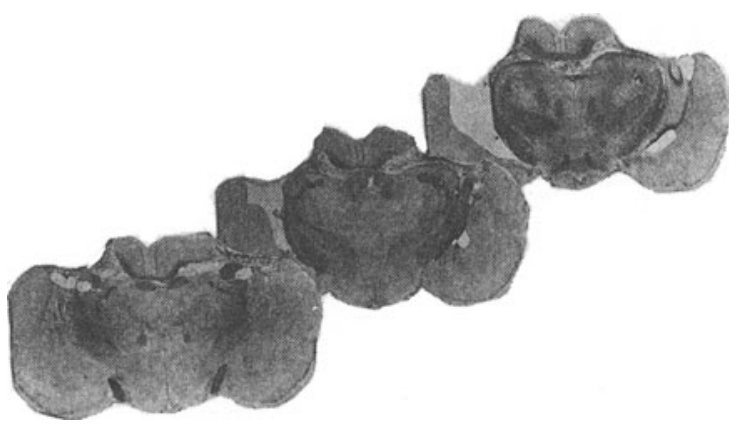


Table 1.

Mean (median) trials to $9 / 10$ criterion, olfactory discrimination.

\begin{tabular}{|c|c|c|c|c|}
\hline Group & Anise + & Peppermint + & Overall & rect, blank tria \\
\hline $\begin{array}{l}\text { Normal } \\
\qquad(N=11)\end{array}$ & $78(69)$ & $84(60)$ & $81(60)$ & $50 \%$ \\
\hline $\begin{array}{l}\text { Cortical } \\
\qquad(N=10)\end{array}$ & $111(90)$ & $83(60)$ & $97(84)$ & $54 \%$ \\
\hline $\begin{array}{l}\text { Hippocampal } \\
\qquad(\mathrm{N}=11)\end{array}$ & $59(58)$ & $112(90)$ & $83(70)$ & $49 \%$ \\
\hline $\begin{array}{l}\text { Overall } \\
\qquad(N=32)\end{array}$ & $83(65)$ & $93(88)$ & $87(74)$ & $51 \%$ \\
\hline
\end{tabular}

acquisition of an olfactory discrimination in the rat. The trend for the hippocampally-lesioned Ss trained to approach peppermint to take almost twice as many trials to reach criterion as those trained to approach anise (a trend not seen in the neocortically-lesioned Ss and noted only slightly in normals) may indicate a subtle effect of hippocampal lesions on olfaction, perhaps altering the affective meaning of odor. Such a modulatory role for the hippocampus, rather than a more explicitly discriminatory role, has been suggested by theorists such as Pribram (1960) and Herrick (1948).

\section{References}

Allen, W. F. Olfactory and trigeminal conditioned reflexes in dogs. Amer. J. Physiol., 1937, 118, 532-540.

Allen, w. F. Effect of ablating the frontal lobes, hippocampi, and occipito-parieto-temporal (excepting pyriform areas) lobes on positive and negative olfactory conditioned reflexes. Amer. J. Physiol., 1940, 128, 754-771.
Allen, W. F. Effect of ablating the pyriform-amygdaloid areas and hippocampi on positive and negative olfactory conditioned reflexes and on conditioned olfactory differentiation. Amer. $J$. Physiol., 1941, 132, 81-92.

Berry, C. M., hagamen, W. D., \& Hinsey, J. C. Distribution of potentials following stimulation of olfactory bulb in cat. $J$. Neurophysiol., 1952, 15, 139-148.

Blackstad, T. W. On the termination of some afferents to the hippocampus and fascia dentata. Acta Anta., 1958, 35, 202-214.

Brown, C. W., \& Ghiselli, E. E. Subcortical mechanisms in learning. IV. Olfactory discrimination. J. comp. Psychol., 1938, 26, 109120 .

Cragg, B. G. Responses of the hippocampus to a stimulation of the olfactory bulb and of various afferent nerves in five mammals. Exp. Neurol., 1960, 2, 547-572.

Cragg, B. G. Olfactory and other afferent connections of the hippocampus in rabbit, rat, and cat. Exp. Neurol., 1961, 3, 588-600.

Herrick, C. J. The brain of the tiger salamander. Chicago: University of Chicago Press, 1948.

Kimble, D. P. The effects of bilateral hippocampal lesions in rats. J. comp. physiol. Psychol., 1963, 56, 273-283.

Pribram, K. H. A review of theory in physiological psychology. Annu. Rev. Psychol., 1960, 11, 1-40.

Pribram, K. H., \& Kruger, L. Functions of the "olfactory brain". Annu. N. Y. Acad. Sci., 1954, 58, 109-138.

Swann, H. G. The function of the brain in olfaction. II. The results of destruction of olfactory and other nervous structures upon the discrimination of odors. J. comp. Neurol., 1934, 59, 175-201.

Swann, H. G. The function of the brain in olfaction. The effects of large cortical lesions on olfactory discrimination. Amer. J. Physiol., 1935, 111, 257-262.

\section{Notes}

1. Supported by USPHS research grant MH-08545-03 from the National Institute of Mental Health, D. P. Kimble, principal investigator. Orders of authors determined by coin toss.

2. Additional histological details supplied upon request. We thank Ruth Bremiller for histology. 